\title{
Phytochemical content and antioxidant activity of extruded products made from yellow corn supplemented with apple pomace powder
}

\author{
Enaim A. Vargas LEÓN${ }^{1}$, Carlos A. Gómez ALDAPA², Jesús Aguayo ROJAS ${ }^{3}$, Apolonio Vargas TORRES 4 , \\ Juan P. Hernández URIBE ${ }^{4}$, Heidi M. Palma RODRÍGUEZ ${ }^{4}$, Ricardo O. Navarro CORTEZ ${ }^{*}$ (D)
}

\begin{abstract}
The aimed of this study was quantified total phenols content, total flavonoids, and antioxidant activity in extruded ready-to-eat products made from yellow corn added with apple pomace powder. A central composite rotatable experimental design was used. The variables tested were exit die temperature $\left(140-180{ }^{\circ} \mathrm{C}\right)$, feed moisture $(14-20 \mathrm{~g} / 100 \mathrm{~g})$ and apple pomace concentration $(0-30 \mathrm{~g} / 100 \mathrm{~g})$. The effect of the process variables on the total contents of phenols, flavonols, flavanols and flavonoids and antioxidant activity was evaluated using the response surface methodology. The data of each response were fitted to a second-order model with determination coefficients $\geq 0.71$. The extruded product with no added apple bagasse showed the lowest values of the evaluated phytochemicals but had higher antioxidant activity by DPPH. The addition of apple pomace increased the phytochemical content and antioxidant activity in extruded ready-to-eat products made with yellow corn. This makes it possible to obtain a formulation of an extruded food rich in phenolic compounds with potential to contribute to prevention of oxidative stress, while making use of agro-industrial waste from apple juice extraction.
\end{abstract}

Keywords: extrusion cooking; response surface methodology; agro industrial waste.

Practical application: The addition of apple pomace into extruded products ready to eat increase the phytochemical content and antioxidant activity.

\section{Introduction}

Fruit pomace is a by-product of the juice extraction industry and has little or no economic value. It is used mainly as organic fertilizer on farms or as animal feed (Paraman et al., 2015). Apple pomace is composed of the solids remaining after extraction of juice, mostly peel, core, seeds and pulp; it is used for extraction of citric acid, pectin, alcohol and biofuels (Reis et al., 2014). Apple pomace is a good source of dietary fiber $(60 \mathrm{~g} / 100 \mathrm{~g})$ and polyphenols (350 mg / 100g) (Paraman et al., 2015). Conventional apple juice production results in a juice that is poor in phenolic compounds with only $3-10 \%$ of the antioxidant activity of the fruit they are produced from. Most of the compounds remain in the apple pomace (Cao et al., 2009), making it a good source of antioxidants. For this reason, it can be used to formulate various food products with beneficial properties for the consumer. In the formulation of these products, it is essential to use techniques that allow quantification of polyphenolic compounds and antioxidant activity to identify the effect of adding apple pomace and of process conditions in the formulation. There are two groups of techniques to evaluate the antioxidant capacity in plant extracts. These techniques are classified in tests by electron transfer (ET) and by hydrogen atom transfer (HAT). Among the electron transfer methods are the ABTS/TEAC, CUPRAC, DPPH, Folin-Ciocalteu and FRAP (Apak et al., 2007). The DPPH radical produces an intense purple solution, reacts with the antioxidants present in the sample of interest, and its color is reduced. Loss of color correlates with the antioxidant activity in the sample of interest (Miller et al., 2000). The reagent 2,2-Diphenyl-1-picrilhidrazil (DPPH) is reduced to its hydrazine form (DPPHH), while the radical ABTS produces a green or blue solution, and when it reacts with the antioxidant compounds in the sample, color intensity decreases (Floegel et al., 2011).

Extrusion cooking is one of the technologies widely used in the preparation of ready-to-eat breakfast cereals, snack foods, pasta, pet food and baby food (Brennan et al., 2011). Mixtures of cereals with fruit by-products, legumes with vegetables, cereals with vegetable by-products, and legumes with tubers have been processed by extrusion in order to increase the phenolic content and antioxidant activity (Altan et al., 2008; Karkle et al., 2012; Paraman et al., 2015; Nayak et al., 2011).

This study aimed to assess the total phenolic content, flavonols, flavanols, total flavonoids and antioxidant activity by DPPH and ABTS in ready-to-eat extruded products made from 
yellow corn and different proportions of apple pomace using response surface methodology.

\section{Materials and methods}

\subsection{Raw materials and flour}

Yellow corn was obtained from a market in Tulancingo de Bravo, Hidalgo, Mexico. The apple pomace was provided by the juice company Yemila, located in Acaxochitlán, Hidalgo, Mexico. The yellow corn grains were ground in a pulvex turbine mill (Model p200, Mexico City, Mexico). The apple bagasse was spread on a tray and dehydrated in an oven (Shel-Lab, model $1380 \mathrm{FX}$, Cornelius, USA) at $60^{\circ} \mathrm{C}$; subsequently, it was ground to a particle size of $120 \mu \mathrm{m}$.

\subsection{Extruded products}

The yellow corn flour and the apple pomace powder were mixed according to the experimental design (Table 1). Once obtained, the mixtures were conditioned with purified water to obtain different moisture conditions (Table 1). The mixtures were placed in polyethylene bags, sealed tightly and allowed to rest for $12 \mathrm{~h}$ until they reached the moisture balance. The mixtures were fed into a single screw laboratory extruder (Brabender, model 19/25, Duisburg, Germany) actuated with a drive unit labstation (Brabender, Duisburg, Germany). The barrel of extruder was grooved and had three heating zones, which were kept at constant temperatures: $80,110,140^{\circ} \mathrm{C}$. Temperature of the exit die was varied according to the design of experiments (Table1). The exit hole of the die was $3 \mathrm{~mm}$. A screw with 3:1 compression ratio was used. The screw speed was constant at $170 \mathrm{rpm}$, and the feed rate was $1.5 \mathrm{~kg} / \mathrm{h}$.

\subsection{Obtaining extracts from raw materials and extruded products}

For each $0.2 \mathrm{~g}$ of sample with a particle size smaller than $250 \mu \mathrm{m}, 1 \mathrm{~mL}$ of $40 \%$ ethanol was added. The solution was shaken in a vortex (model LabDancer, IKA, Staufen, Germany) for $1 \mathrm{~min}$ and allowed to stand for $5 \mathrm{~min}$, then centrifuged at 12,000 rpm for 15 min using a microcentrifuge (model Xc-MiniSpin plus, Eppedorf, Hamburgo, Germany). The procedure was repeated 3 times to obtain $3 \mathrm{~mL}$ of extract of each treatment. The $3 \mathrm{~mL}$ of extract was placed in a $10 \mathrm{~mL}$ volumetric flask, gauging the missing volume with $40 \%$ ethanol.

\subsection{Quantification of total phenolic content}

Quantification of total phenolic compounds was carried out according to the methodology of Pękal \& Pyrzynska (2014).
First, $125 \mu \mathrm{L}$ of extract, $125 \mu \mathrm{L}$ of aqueous ethanol (50:50 v/v), $625 \mu \mathrm{L}$ of folin reagent $(10 \%, v / v)$, and $500 \mu \mathrm{L}$ of $\mathrm{Na}_{2} \mathrm{CO}_{3}(7 \%$, $\mathrm{w} / \mathrm{v}$ ) were reacted for $2 \mathrm{~h}$ in the dark at room temperature. After the reaction time, absorbance was measured at $760 \mathrm{~nm}$ in a spectrophotometer (model Genesys 10s UV-vis, Thermo Fisher Scientific, Massachusset, USA). The results were expressed as $\mathrm{mg}$ gallic acid equivalents/100 g dry sample.

\subsection{Quantification of flavonoids}

The first assay consisted of reacting $1 \mathrm{~mL}$ of extract with $100 \mu \mathrm{L}$ of $\mathrm{NaNO}_{2}(5 \%, \mathrm{w} / \mathrm{v})$ and $100 \mu \mathrm{L}$ of $\mathrm{AlCl}_{3}(10 \%$, w/v) in an alkaline medium for $5 \mathrm{~min}$. Absorbance was read at $510 \mathrm{~nm}$, and the results were expressed as $\mathrm{mg}$ catechin equivalents $(\mathrm{mg}$ $\mathrm{CE} / 100 \mathrm{~g}$ dry sample). The second assay consisted of reacting $1 \mathrm{~mL}$ of extract with $100 \mu \mathrm{L}$ of $\mathrm{AlCl}_{3}(10 \%$, w/v) for $5 \mathrm{~min}$; absorbance was read at $425 \mathrm{~nm}$. The results were expressed as mg quercetin equivalents (mg QE /100 g dry sample) (Pękal \& Pyrzynska, 2014).

\subsection{Antioxidant activity by DPPH}

Total antioxidant capacity was determined following the method proposed by Brand-Williams et al. (1995). Fifty $\mu \mathrm{L}$ of extract was reacted with $1050 \mu \mathrm{L}$ of the 2,2-diphenyl-1-picrylhydrazine radical (DPPH) for $30 \mathrm{~min}$ in the dark. Absorbance was measured at $515 \mathrm{~nm}$, and results were expressed as milligrams ascorbic acid equivalent/100 g dry sample (mg AAE/100 g).

\subsection{Antioxidant activity by ABTS}

This determination was made according to Re et al. (1999). The radical 2,2-azino-bis (3-ethylbezothiazoline-6 sulfonic acid) (ABTS) $(7 \mathrm{mM})$ reacted with $\mathrm{K}_{2} \mathrm{~S}_{2} \mathrm{O}_{8}(2.45 \mathrm{mM})$ for $16 \mathrm{~h}$ in the dark at room temperature $\left(24 \pm 1^{\circ} \mathrm{C}\right)$. Subsequently, $1050 \mu \mathrm{L}$ of the formed radical was mixed with $50 \mu \mathrm{L}$ of extract, and the mixture was allowed to react for $30 \mathrm{~min}$ in the dark. Absorbance was measured at $732 \mathrm{~nm}$; the results were expressed as milligrams of trolox equivalent / $100 \mathrm{~g}$ dry sample (mg TE/100 g).

\subsection{Statistical analysis}

The experimental data were analyzed with response surface methodology, using the Design Expert 7.1.5 statistical package (Stat-ease INC., Minneapolis, USA). The experimental data were fitted to a quadratic model and the regression coefficients were obtained. The statistical significance of the regression terms for each evaluated response was obtained through of an analysis of variance (ANOVA). The model obtained was the following Equation 1:

Table 1. Central composite rotatable experimental design with three factors $(\alpha=1.682)$ and coded levels used in the extrusion process.

\begin{tabular}{ccccccc}
\hline Variables & \multirow{2}{*}{ Coded } & \multicolumn{5}{c}{ Levels } \\
\cline { 3 - 7 } & & $-\alpha$ & -1 & 0 & +1 \\
\hline Temperature of die $\left({ }^{\circ} \mathrm{C}\right)$ & $\mathrm{X}_{1}$ & 140 & 148 & 160 & 172 \\
Moisture fed $(\mathrm{g} / 100 \mathrm{~g})$ & $\mathrm{X}_{2}$ & 14 & 15.2 & 17.0 & 18.8 & 20 \\
Concentration of apple pomace $(\mathrm{g} / 100 \mathrm{~g})$ & $\mathrm{X}_{3}$ & 0 & 6 & 10 & 14 & 30 \\
\hline
\end{tabular}


$y=\beta o+\beta_{1} X_{1}+\beta_{2} X_{2}+\beta_{3} X_{3}+\beta_{11} X_{1}^{2}+\beta_{22} X_{2}^{2}+\beta_{33} X_{3}^{2}+\beta_{12} X_{1} X_{2}+\beta_{13} X_{1} X_{3}+\beta_{23} X_{2} X_{3}$

\section{Results and discussion}

\subsection{Total phenols content, total flavonoids and antioxidant activity in raw mixtures from yellow corn and apple pomace}

Table 2 shows that apple pomace has the highest content of phytochemicals analyzed, as well as the highest antioxidant activity by ABTS; while, yellow corn flour has highest value for DPPH. In the mixtures, the addition of apple pomace increases the phytochemical content. The mixture with $30 \mathrm{~g} / 100 \mathrm{~g}$ of apple pomace presented the highest total phenolic content (TPC) and total flavonoid content (TFC). The mixture 94:6 YC:AP presented the highest antioxidant activity by DPPH, while the mixture 76:24 YC:AP presented the highest antioxidant activity by ABTS. Apple pomace had three times more TPC and eleven times more TFC than yellow corn. The content of phenols in apple pomace found in our study was lower than that reported by Drożdż et al. (2014) and Lohani et al. (2016); however, antioxidant activity was higher than that reported by the authors mentioned. With respect to the content of total phenols in yellow corn, the values obtained are lower than those reported by Parra et al. (2007) and by Mora-Rochin et al. (2010), but total flavonoid content and antioxidant activity were higher by ABTS than those reported by Žilić et al. (2012). The differences in the content of phenolic compounds between our findings and those of other authors can be attributed to the genetic background, the relation of structural components of the grain (Parra et al., 2007), since the pericarp and layer of the aleurone have the highest contents of phenolic compounds in cereals (López-Martínez et al., 2009; LopezMartínez et al., 2011). The antioxidant activity of all samples using the ABTS assay was higher than that determined with the DPPH method (Table 2) because ABTS can react with a wider range of antioxidant compounds including both hydrophilic and lipophilic compounds, and it is also reduced by aromatic $\mathrm{OH}$-groups that do not significantly contribute to antioxidant activity. In contrast, DPPH is more selective to hydrogen-donor compounds and does not react with aromatic acids containing only one $\mathrm{OH}$ group (Vázquez-Carrillo et al., 2018). Quercetin has been reported to have structural advantages as an antioxidant because the $O$-dihydroxy moiety in the B ring confers stability to the resulting free radical form. Quercetin is mainly present in apple peel, and in apple pomace the peel makes up a high percentage. In various studies, this compound has shown the highest antioxidant capacity in the ABTS radical scavenging assay (Lee et al., 2003).

\subsection{Total phenols content in extruded products}

Figure la shows the effect of die temperature and feed moisture at an apple bagasse concentration of $15 \mathrm{~g} / 100 \mathrm{~g}$ of sample on TPC, while Figure $1 \mathrm{~b}$ shows the effect of die temperature and concentration of apple pomace on the TPC at $17 \mathrm{~g} / 100 \mathrm{~g}$ d.b. feed moisture. In Figure 1a, the highest content of TPC was obtained when the extrusion temperature reached $180^{\circ} \mathrm{C}$ with $20 \mathrm{~g} / 100 \mathrm{~g}$ feed moisture, while in Figure $1 \mathrm{~b}$ the content of total phenols increases with increasing apple bagasse concentrations at any exit die temperature tested. Phenolic content of the extruded products was in a range of $61.25 \pm 1.67$ to $187.65 \pm 10.40 \mathrm{mg}$ GAE/100 g of sample.

Retention of TPC in the extruded product without apple pomace was $62 \%$, while retention was $100 \%$ for the extrudate with higher apple pomace content. These percentages were calculated with respect to the mixture before the extrusion process and are superior to those reported by Paraman et al. (2015) in extruded products obtained from pregelatinized corn starch and whey concentrate with apple pomace added at concentrations of 22 and $28 \mathrm{~g} / 100 \mathrm{~g}$. The higher retention and stability of the bioactive phenolics in extruded products from cereals and fruits is probably attributed to the short thermal processing time of raw materials; moreover, during the extrusion cooking process, there are no physical losses of the anatomical components of maize grain. This is important since the health benefits of whole grains over refined ones are mainly attributed to the presence of higher levels of various bioactive phytochemicals in the bran (Okarter et al., 2010; Aguayo-Rojas et al., 2012).

\subsection{Quantification of flavonoids in extruded products}

Figures $2 a, 2 b$ and $2 c$ show the effect of exit die temperature, apple pomace concentration and

The Figure 2a graph is saddle-shaped, indicating that flavonoid content is affected by feed moisture, as well as by the exit die temperature. The maximum flavonoid content was obtained at the exit die temperature of $160^{\circ} \mathrm{C}$ and feed moisture of $14 \mathrm{~g} / 100 \mathrm{~g}$. The contents of flavonoids in the extruded products range from $42.84 \pm 3.85$ to $96.14 \pm 0.57 \mathrm{mg} / 100 \mathrm{~g}$. Figures $2 \mathrm{~b}$ and $2 \mathrm{c}$ show an increase in the content of flavonoids when the concentration of apple bagasse increases at any exit

Table 2. Total phenolic content (TPC), total flavonoids content (TFC), antioxidant activity by DPPH and ABTS of mixtures of yellow corn (YC) and apple pomace (AP) before being processed by extrusion cooking.

\begin{tabular}{ccccc}
\hline Mixture & $\begin{array}{c}\text { TPC } \\
(\mathrm{mg} \mathrm{GAE} / 100 \mathrm{~g})\end{array}$ & $\begin{array}{c}\text { TFC } \\
(\mathrm{mg} / 100 \mathrm{~g})\end{array}$ & $\begin{array}{c}\text { DDPH } \\
(\mu \mathrm{M} \mathrm{AAE} / 100 \mathrm{~g})\end{array}$ & $\begin{array}{c}\text { ABS } \\
(\mu \mathrm{M} \text { TE/ 100g })\end{array}$ \\
\hline AP & $327.60 \pm 3.33$ & $75.59 \pm 3.31$ & $906.92 \pm 40.24$ & $3829.39 \pm 11.30$ \\
100:0 YC:AP & $98.58 \pm 2.79$ & $6.73 \pm 0.39$ & $1346.64 \pm 49.94$ & $3239.95 \pm 38.45$ \\
94:6 YC:AP & $77.54 \pm 2.60$ & $8.10 \pm 0.04$ & $1415.16 \pm 30.60$ & $2174.52 \pm 39.15$ \\
85:15 YC:AP & $145.72 \pm 4.77$ & $19.89 \pm 0.38$ & $1254.45 \pm 21.10$ & $3210.35 \pm 82.39$ \\
76:24 YC:AP & $167.59 \pm 7.53$ & $27.00 \pm 0.75$ & $1281.37 \pm 47.35$ & $3789.93 \pm 61.61$ \\
70:30 YC:AP & $185.69 \pm 2.29$ & $29.30 \pm 0.83$ & $1300.95 \pm 22.07$ & $3755.40 \pm 82.50$ \\
\hline
\end{tabular}




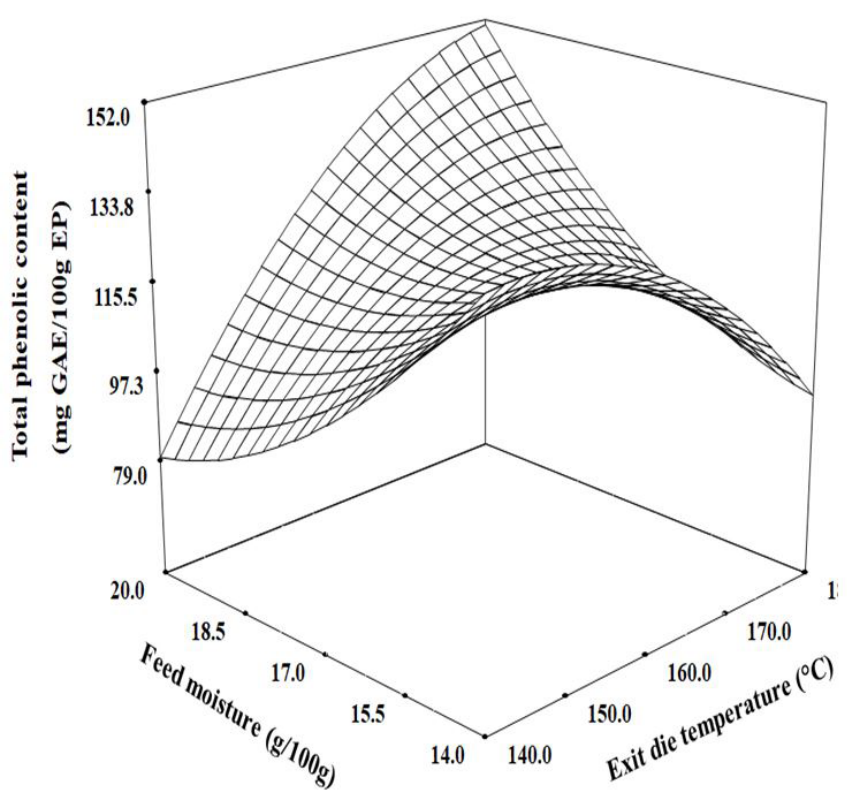

$\mathbf{a}$

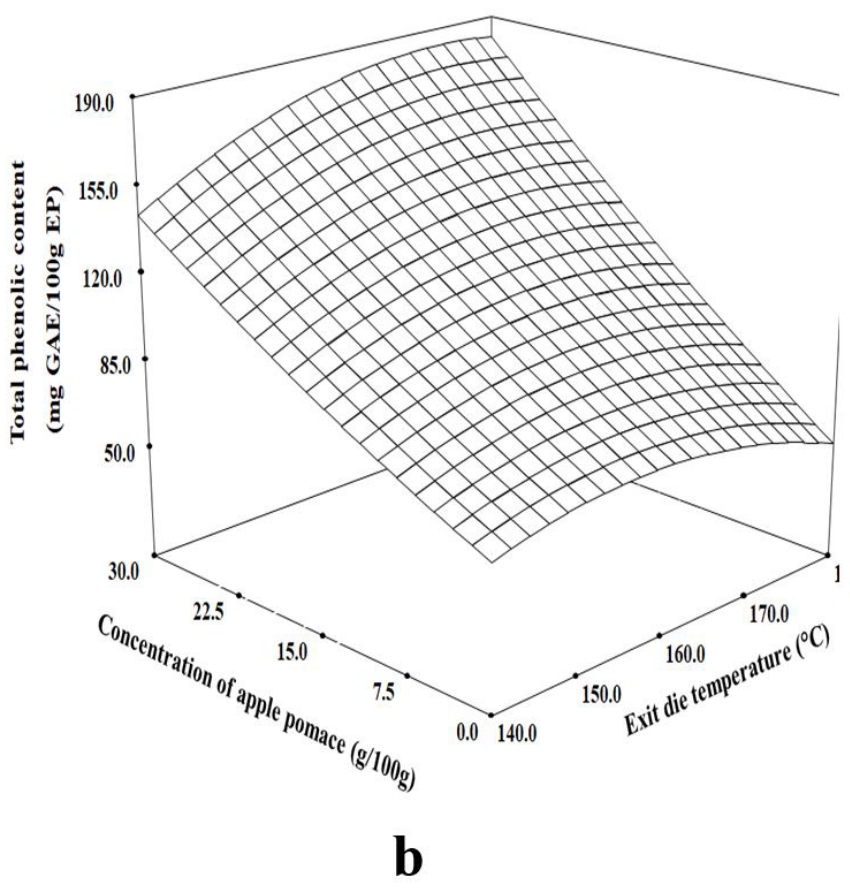

Figure 1. Response surface plot three-dimensional of total phenolic content $\left(\mathrm{y}=819.57+2.60 \mathrm{X}_{1}-112.81 \mathrm{X}_{2}-0.33 \mathrm{X}_{3}+0.48 \mathrm{X}_{1,2}+0.04 \mathrm{X}_{1,3}-0.19 \mathrm{X}_{2,3}\right.$ $\left.-0.04 \mathrm{X}_{1,1}+1.12 \mathrm{X}_{2,2}+0.02 \mathrm{X}_{3,3}\right), \mathrm{R}^{2}=0.84$. Effect of exit die temperature and feed moisture $(\mathrm{a})$, concentration of apple pomace $=15.0 \mathrm{~g} / 100 \mathrm{~g}$; and effect of exit die temperature and concentration of apple pomace (b), feed moisture $=17.0 \mathrm{~g} / 100 \mathrm{~g}$.

die temperature and feed moisture tested. Figure $2 \mathrm{~b}$ shows that the highest TFC was obtained at exit die temperatures between 170 and $180^{\circ} \mathrm{C}$ and a concentration of apple pomace of $30 \mathrm{~g} / 100 \mathrm{~g}$, while Figure $2 \mathrm{c}$ shows that the highest TFC was obtained at a feed moisture of $20 \mathrm{~g} / 100 \mathrm{~g}$ and an apple pomace concentration of $30 \mathrm{~g} / 100 \mathrm{~g}$. Flavonoids are heat sensitive and susceptible to thermal destruction. Thermal stability (retention/ degradation) of flavonoids is affected by different factors such as the nature of the matrix, type of processing, or temperatures used (Moussa-Ayoub et al., 2015).

\subsection{Evaluation of antioxidant activity by DPPH in extruded products}

Antioxidant activity and antiradical activity of extruded products is dependent not only on the level of bioactive compounds but also on their composition. Pigmented maize has been reported to be a valuable source of phytochemicals, mainly phenolic acids, anthocyanins, and carotenoids (Brennan et al., 2011; Corrales-Bañuelos et al., 2016). Apple pomace contains several phytochemicals such as catechin, procyanidin, phloridzine, phloretin, ferulic acid, caffeic acid, quercetinglucoside and cyanidin-glucoside (Leyva-Corral et al., 2016). Figures $3 a, 3 b$ and $3 c$ show the effect of exit die temperature, feed moisture and apple pomace concentration on antioxidant activity by DPPH. Figure 3a shows the saddle-shaped behavior, where the highest antioxidant activity is found at low temperatures $\left(140{ }^{\circ} \mathrm{C}\right)$ and feed moisture of $17 \mathrm{~g} / 100 \mathrm{~g}$, as well as at high temperatures $\left(180^{\circ} \mathrm{C}\right)$ and feed moisture of $17 \mathrm{~g} / 100 \mathrm{~g}$. The lowest antioxidant activity was obtained at a temperature of $160^{\circ} \mathrm{C}$ and feed moisture of $14 \mathrm{~g} / 100 \mathrm{~g}$. Figure $3 \mathrm{~b}$ shows that the highest antioxidant activity was obtained in the product to which apple bagasse was not added. At high temperature $\left(180^{\circ} \mathrm{C}\right)$ and increasing apple bagasse concentration, the capacity to neutralize the radical DPPH decreases. In the Figure 3c, the highest antioxidant activity by DPPH was found at feed moisture between 15.5 and $18 \mathrm{~g} / 100 \mathrm{~g}$ with no added apple pomace. Antioxidant activity decreases when feed moisture is below $15.5 \mathrm{~g} / 100 \mathrm{~g}$ and above $18 \mathrm{~g} / 100 \mathrm{~g}$, as well as when apple pomace concentration increases. Rocha-Guzmán et al. (2012) reported that the addition of pumpkin flour in extruded product made from yellow corn decreases antioxidant activity by DPPH. Most of the bioactive compounds are temperature sensitive; hence, barrel temperature plays a significant role in the stability of these phytochemicals. It has been inferred that high temperatures during extrusion are detrimental to the phenolic compounds and to antioxidant activity as well (Lopez-Martinez et al., 2011; Zeng et al., 2018). Miller et al. (2000) reported that whole grains possess greater antioxidant activity than refined grains and some fruits. Phenolic acids are the main compounds responsible for antioxidant activity in maize; hydroxycinnamic acids (ferulic and the p-coumaric acids) are present in corn and apple pomace (Chiremba et al., 2012; Leyva-Corral et al., 2016). In some cases, the level of bioactive compounds in extruded products may increase, for example ferulic acid content is reported to triple in extruded cereal grains, affecting the antioxidant activity (Zieliński et al., 2001), denaturation of grain proteins during extrusion promotes tannin-protein interaction, the formation of tannin-protein complexes retain antioxidant activity (Brennan et al., 2011). 


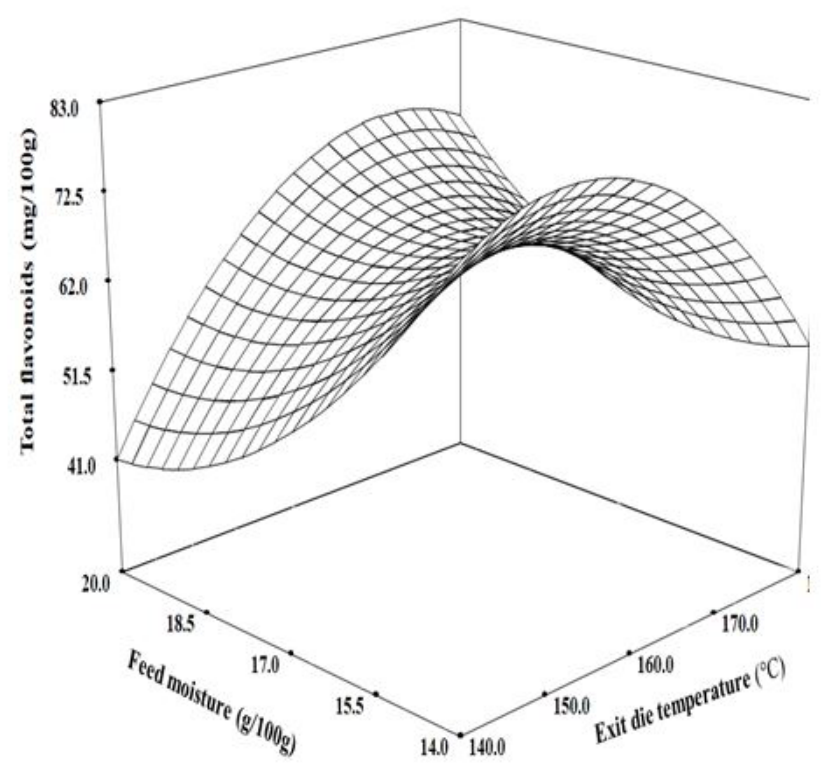

$\mathbf{a}$

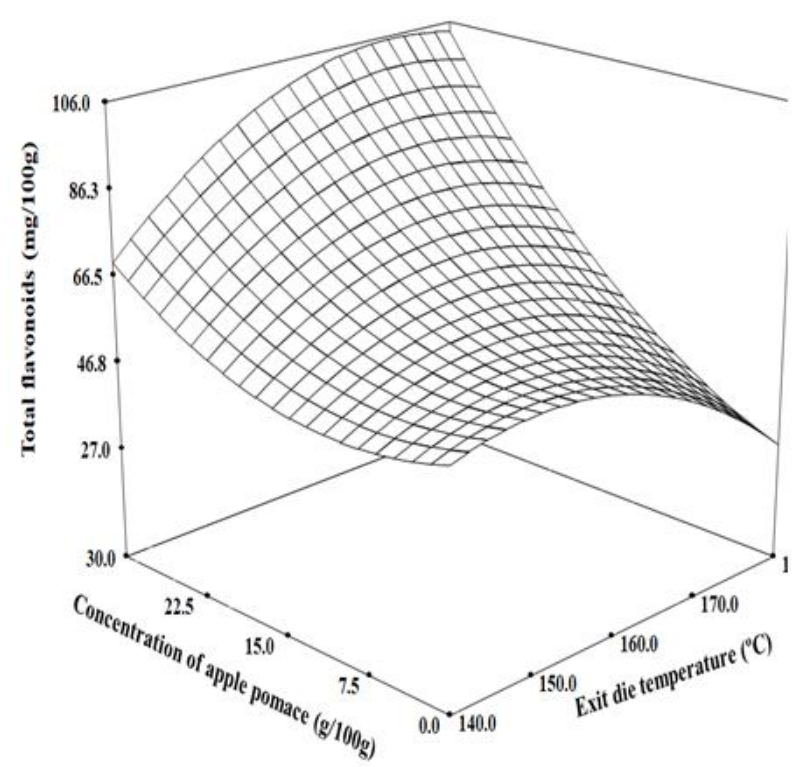

b

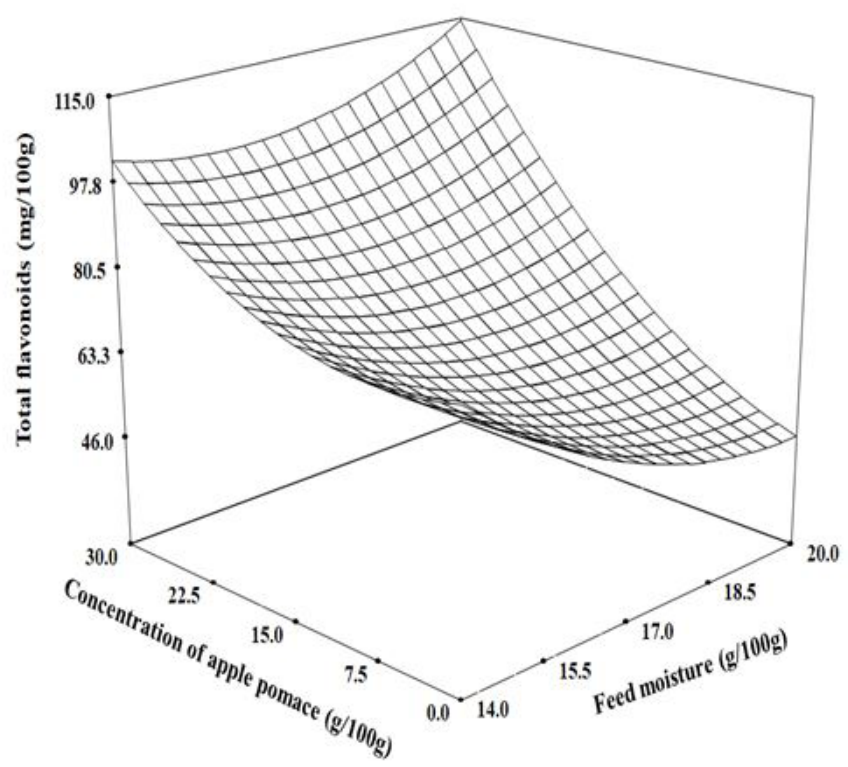

c

Figure 2. Response surface plot three-dimensional of total flavonoids $\left(\mathrm{y}=272.26+6.19 \mathrm{X}_{1}-72.16 \mathrm{X}_{2}-12.15 \mathrm{X}_{3}+0.22 \mathrm{X}_{1,2}+0.05 \mathrm{X}_{1,3}+0.25 \mathrm{X}_{2,3}-\right.$ $\left.0.03 \mathrm{X}_{1,1}+0.92 \mathrm{X}_{2,2}+0.05 \mathrm{X}_{3,3}\right), \mathrm{R}^{2}=0.77$. Effect of exit die temperature and feed moisture (a), concentration of apple pomace $=15.0 \mathrm{~g} / 100 \mathrm{~g} ;$ effect of exit die temperature and concentration of apple pomace (b), feed moisture $=17.0 \mathrm{~g} / 100 \mathrm{~g}$; and effect of feed moisture and concentration of apple pomace (c), temperature edit die $=160^{\circ} \mathrm{C}$.

\subsection{Evaluation of antioxidant activity by ABTS in extruded products}

Figures $4 \mathrm{a}$ and $4 \mathrm{~b}$ show the effect of exit die temperature, feed moisture and apple pomace concentration on antioxidant activity using the ABTS radical. Graph 4a shows that antioxidant activity decreases when the temperature is lower or higher than $160^{\circ} \mathrm{C}$ at a feed moisture of $20 \mathrm{~g} / 100 \mathrm{~g}$, and the lowest antioxidant activity was obtained at low temperature $\left(140{ }^{\circ} \mathrm{C}\right)$ and high temperature $\left(180^{\circ} \mathrm{C}\right)$ at a feed moisture of $17 \mathrm{~g} / 100 \mathrm{~g}$. In Figure $4 \mathrm{~b}$ there are two areas where the highest antioxidant capacity is obtained. One of them is located at feed moisture of $14 \mathrm{~g} / 100 \mathrm{~g}$ and an apple pomace concentration of 


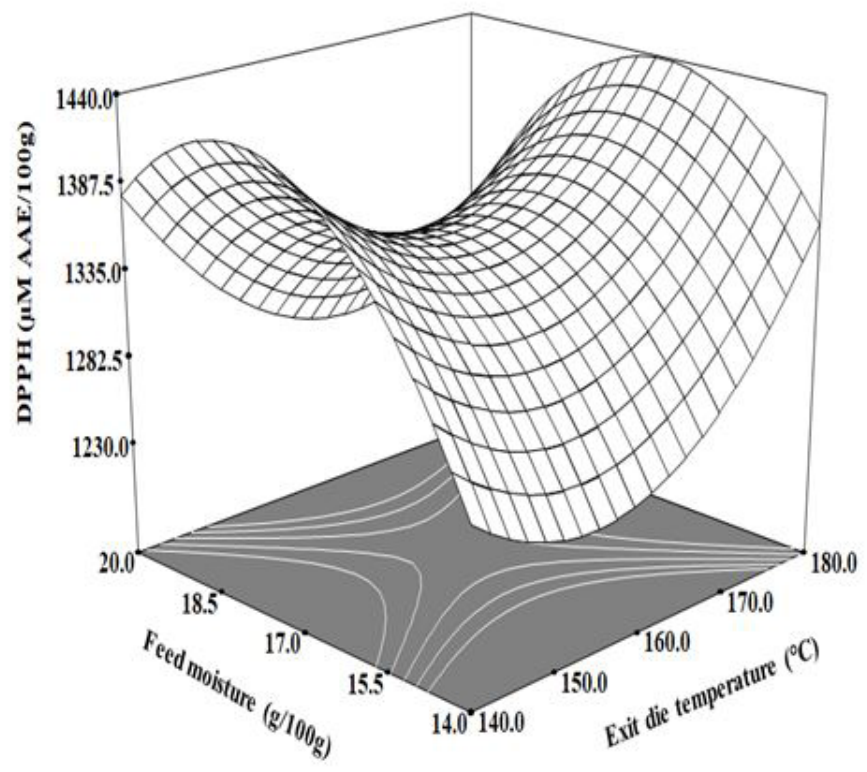

$\mathbf{a}$

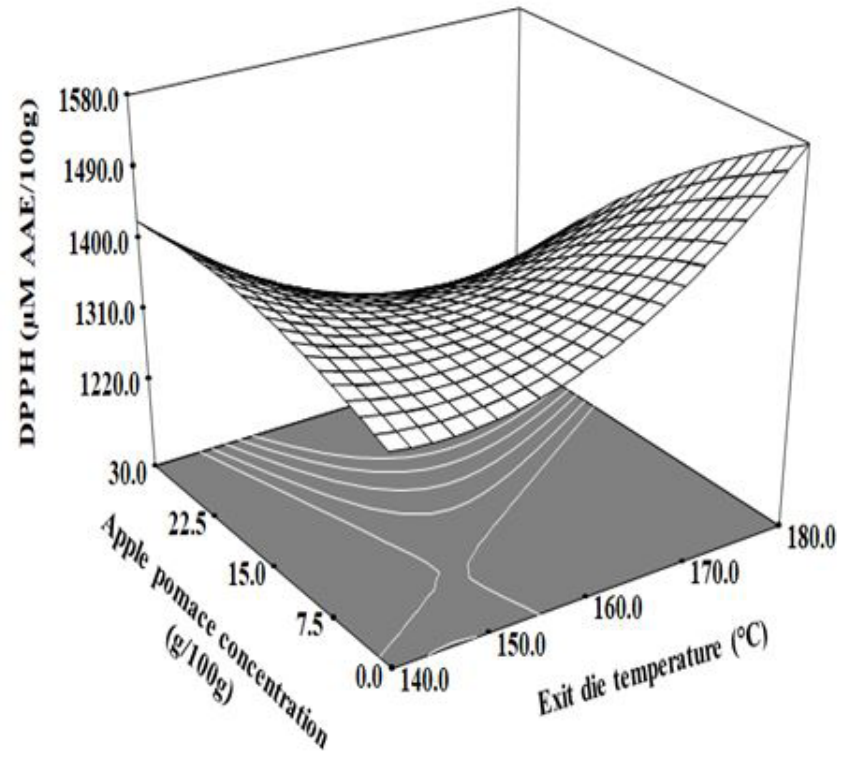

b

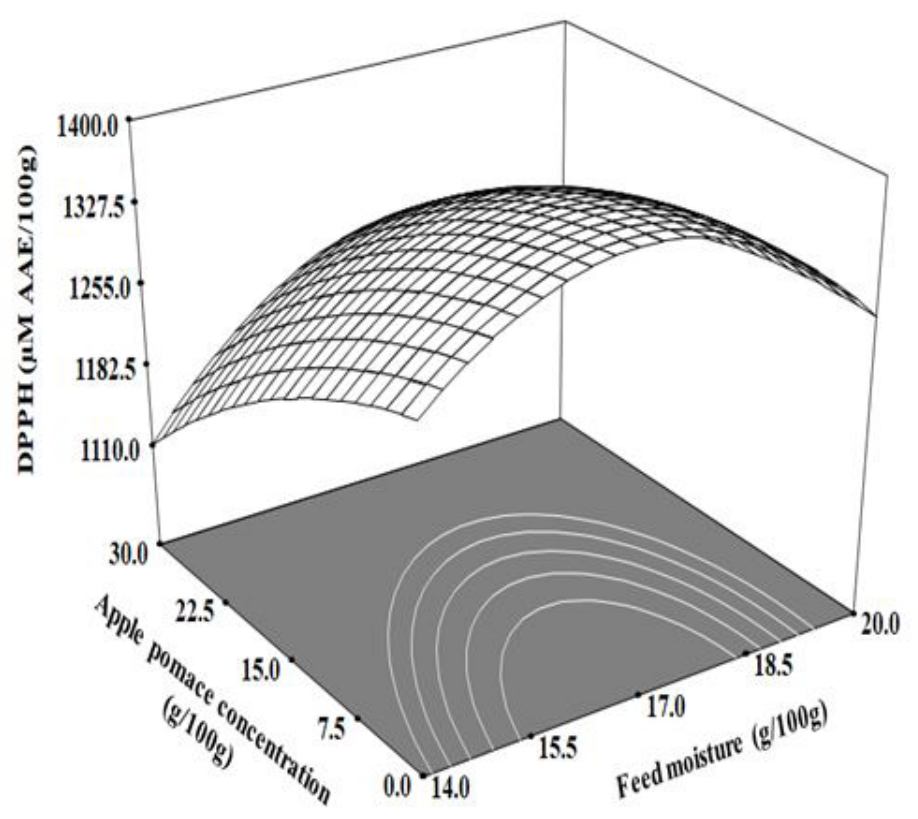

c

Figure 3. Response surface plot three-dimensional of antioxidant activity by DPPH $\left(\mathrm{y}=140.23+0.27 \mathrm{X}_{1}+0.10 \mathrm{X}_{2}+10.80 \mathrm{X}_{3}+0.35 \mathrm{X}_{1,2}-0.15 \mathrm{X}_{1,3}\right.$ $\left.+0.75 \mathrm{X}_{23}-0.01 \mathrm{X}_{1,1}-1.95 \mathrm{X}_{2,2}-0.01 \mathrm{X}_{3,3}\right), \mathrm{R}^{2}=0.72$. Effect of exit die temperature and feed moisture (a), concentration of apple pomace $=15.0$ $\mathrm{g} / 100 \mathrm{~g}$; effect of exit die temperature and concentration of apple pomace (b), feed moisture $=17.0 \mathrm{~g} / 100 \mathrm{~g}$; and effect of feed moisture and concentration of apple pomace (c), temperature edit die $=160^{\circ} \mathrm{C}$.

$24 \mathrm{~g} / 100 \mathrm{~g}$, while the other area is obtained at an apple pomace concentration of $6 \mathrm{~g} / 100 \mathrm{~g}$ at feed moisture of $20 \mathrm{~g} / 100 \mathrm{~g}$. The antioxidant activity in the extruded products by ABTS is between $2001.88 \pm 85.11$ and $3871.31 \pm 11.30 \mu \mathrm{m} / 100 \mathrm{~g}$. To some extent, higher moisture content has a protective effect on the bioactive compounds. Some reports have shown that thermal degradation of phenolic compounds may be due to complex formation by reaction with Maillard by-products, and high moisture content promotes phenolic compound polymerization of phenols and tannins leading to reduced extractability and antioxidant activity (Remy et al., 2000; Dlamini et al., 2007). In contrast, transformation in more easily extractable forms of 


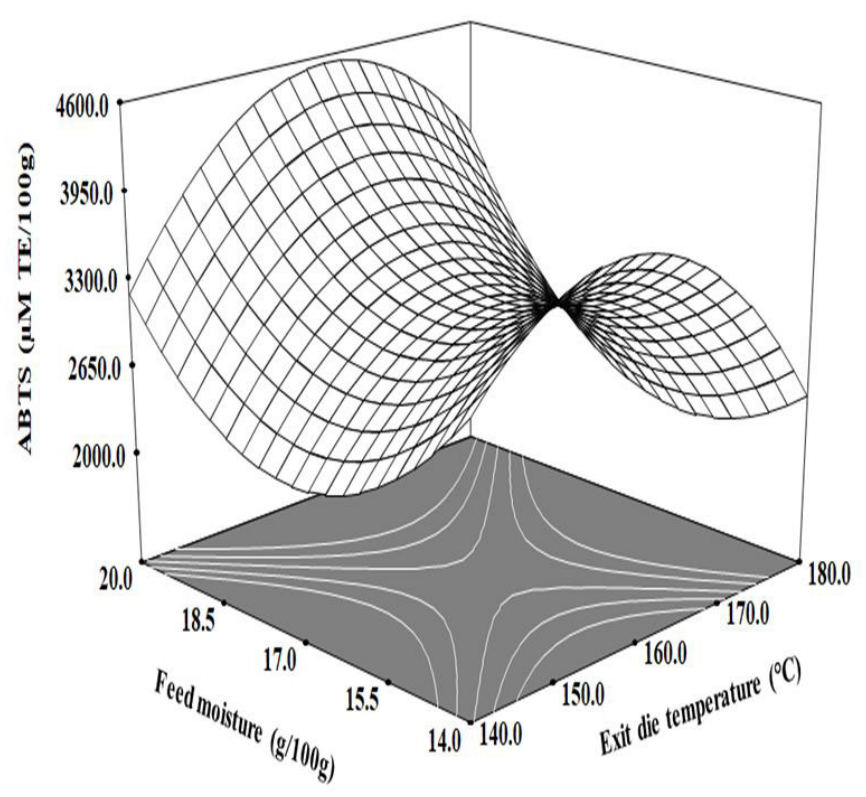

a

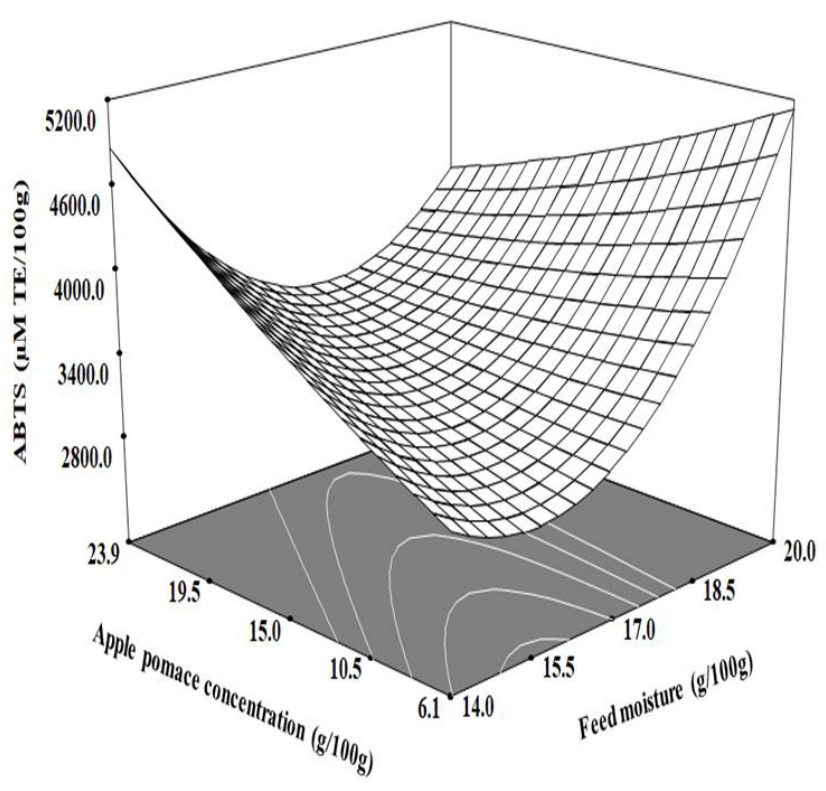

b

Figure 4. Response surface plot three-dimensional of antioxidant activity by ABTS $\left(\mathrm{y}=-4418.85+132.12 \mathrm{X}_{1}-695.69 \mathrm{X}_{2}+73.04 \mathrm{X}_{3}+1.36 \mathrm{X}_{1,2}+\right.$ $\left.0.17 \mathrm{X}_{1,3}-6.60 \mathrm{X}_{2,3}-0.50 \mathrm{X}_{1,1}-17.07 \mathrm{X}_{2,2}+0.55 \mathrm{X}_{3,3}\right), \mathrm{R}^{2}=0.77$. Effect of exit die temperature and feed moisture (a), concentration of apple pomace $=15.0 \mathrm{~g} / 100 \mathrm{~g}$; and effect of feed moisture and concentration of apple pomace $(\mathrm{b})$, temperature edit die $=160{ }^{\circ} \mathrm{C}$.

phenolic compounds has been reported in single screw extruders with low moisture contents ( $<15 \mathrm{~g} / 100 \mathrm{~g})$, high shear stress, and high temperatures (Awika et al., 2003). All these chemical changes are associated with structural changes that occur in the materials subjected to extrusion, increasing the release of the bioactive compounds contained in the cell wall matrix and making these materials more easily extractable for antioxidant capacity quantification (Zieliński et al., 2006; Reyes et al., 2007). The loss of natural antioxidants during extrusion above $80^{\circ} \mathrm{C}$ has been attributed to their low resistance to heat, evaporation and decomposition at these elevated temperatures. It has also been reported that high temperature during extrusion alters the molecular structure of phenolic compounds and can reduce their chemical reactivity, thus decreasing their extractability due to a certain degree of polymerization and causing loss of antioxidant properties (Nayak et al., 2015).

\section{Conclusions}

The addition of apple pomace to yellow corn flour improved phytochemical content and antioxidant activity. The phytochemical compounds and antioxidant activity of extruded products from yellow corn flour and powdered apple pomace are modified by the factors tested during extrusion cooking process. Apple pomace can be added to extruded products to increase the phytochemical content and improve antioxidant activity, obtaining foods with functional characteristics since the presence of phenolic compounds is associated with the prevention of chronic degenerative diseases, associated with oxidative stress. Furthermore, this by-product of apple juice extraction would acquire added value. The extrusion process solubilizes the phytochemicals bound in the pericarp of corn and the peel in the apple pomace making them more available to react.

\section{References}

Aguayo-Rojas, J., Mora-Rochín, S., Cuevas-Rodríguez, E. O., SernaSaldívar, S. O., Gutiérrez-Uribe, J. A., Reyes-Moreno, C., \& MilánCarrillo, J. (2012). Phytochemicals and antioxidant capacity of tortillas obtained after lime-cooking extrusión process of whole pigmented Mexican maize. Plant Foods for Human Nutrition, 67(2), 178-185. http://dx.doi.org/10.1007/s11130-012-0288-y. PMid:22562094.

Altan, A., McCarthy, K. L., \& Maskan, M. (2008). Evaluation of snack foods from barley-tomato pomace blends by extrusion processing. Journal of Food Engineering, 84(2), 231-242. http://dx.doi.org/10.1016/j. jfoodeng.2007.05.014.

Apak, R., Güçlü, K., Demirata, B., Özyürek, M., \& Çelik, S. E. (2007). Comparative evaluation of various total antioxidant capacity assay applied to phemolic compounds with the CUPRAC assay. Molecules, 12(7), 1496-1547.http://dx.doi.org/10.3390/12071496. PMid:17909504.

Awika, J. M., Rooney, L. W., Wu, X. L., Prior, R. L., \& Cisneros-Zevallos, L. (2003). Screening methods to measure antioxidant activity of sorghum (Sorghum bicolor) and sorghum products. Journal of Agricultural and Food Chemistry, 51(23), 6657-6662. http://dx.doi. org/10.1021/jf034790i. PMid:14582956.

Brand-Williams, W., Cuvelier, M. E., \& Berset, C. L. W. T. (1995). Use of a free radical method to evaluate antioxidant activity. LebensmittelWissenschaft + Technologie, 28(1), 25-30. http://dx.doi.org/10.1016/ S0023-6438(95)80008-5.

Brennan, C., Brennan, M., Derbyshire, E., \& Tiwari, B. K. (2011). Effects of extrusion on the polyphenols, vitamins, and antioxidant activity 
of foods. Trends in Food Science \& Technology, 22(10), 570-575. http://dx.doi.org/10.1016/j.tifs.2011.05.007.

Cao, X., Wang, C., Pei, H., \& Sun, B. (2009). Separation and identification of polyphenols in apple pomace by high-speed counter-current chromatography and high-performance liquid chromatography coupled with mass spectrometry. Journal of Chromatography. A, 1216(19), 4268-4274. http://dx.doi.org/10.1016/j.chroma.2009.01.046. PMid:19203755.

Chiremba, C., Taylor, J. R., Rooney, L. W., \& Beta, T. (2012). Phenolic acid content of sorghum and maize cultivars varying in hardness. Food Chemistry, 134(1), 81-88. http://dx.doi.org/10.1016/j. foodchem.2012.02.067.

Corrales-Bañuelos, A. B., Cuevas-Rodríguez, E. O., Gutiérrez-Uribe, J. A., Milán-Noris, E. M., Reyes-Moreno, C., Milán-Carrillo, J., \& Mora-Rochín, S. (2016). Carotenoid composition and antioxidant activity of tortillas elaborated from pigmented maize landrace by traditional nixtamalization or lime cooking extrusion process. Journal of Cereal Science, 69, 64-70. http://dx.doi.org/10.1016/j. jcs.2016.02.009.

Dlamini, N. R., Taylor, J. R., \& Rooney, L. W. (2007). The effect of sorghum type and processing on the antioxidant properties of African sorghum-based foods. Food Chemistry, 105(4), 1412-1419. http://dx.doi.org/10.1016/j.foodchem.2007.05.017.

Drożdż, W., Tomaszewska-Ciosk, E., Zdybel, E., Boruczkowska, H., Boruczkowski, T., \& Regiec, P. (2014). Effect of apple and rosehip pomaces on colour, total phenolics and antioxidant activity of corn extruded snacks. Polish Journal of Chemical Technology, 16(3), 7-11. http://dx.doi.org/10.2478/pjct-2014-0042.

Floegel, A., Kim, D. O., Chung, S. J., Koo, S. I., \& Chun, O. K. (2011). Comparison of ABTS/DPPH assays to measure antioxidant capacity in popular antioxidant rich US foods. Journal of Food Composition and Analysis, 24(7), 1043-1048. http://dx.doi.org/10.1016/j. jfca.2011.01.008.

Karkle, E. L., Alavi, S., \& Dogan, H. (2012). Cellular architecture and its relationship with mechanical properties in expanded extrudates containing apple pomace. Food Research International, 46(1), 10-21. http://dx.doi.org/10.1016/j.foodres.2011.11.003.

Lee, K. W., Kim, Y. J., Kim, D. O., Lee, H. J., \& Lee, C. Y. (2003). Major phenolics in apple and their contribution to the total antioxidant capacity. Journal of Agricultural and Food Chemistry, 51(22), 65166520. http://dx.doi.org/10.1021/jf034475w. PMid:14558772.

Leyva-Corral, J., Quintero-Ramos, A., Camacho-Dávila, A., ZazuetaMorales, J. J., Aguilar-Palazuelos, E., Ruiz-Gutiérrez, M. G., MeléndezPizarro, C. O., \& Ruiz-Anchondo, T. J. (2016). Polyphenolic compound stability and antioxidant capacity of apple pomace in an extruded cereal. Lebensmittel-Wissenschaft + Technologie, 65, 228-236. http:// dx.doi.org/10.1016/j.lwt.2015.07.073.

Lohani, U. C., Muthukumarappan, K., \& Meletharayil, G. H. (2016). Application of hydrodynamic cavitation to improve antioxidant activity in sorghum flour and apple pomace. Food and Bioproducts Processing, 100, 335-343. http://dx.doi.org/10.1016/j.fbp.2016.08.005.

López-Martínez, L. X., Oliart-Ros, R. M., Valerio-Alfaro, G., Lee, C. H., Parkin, K. L., \& Garcia, H. S. (2009). Antioxidant activity, phenolic compounds and anthocyanins content of eighteen strains of Mexican maize. Journal of Food Science and Technology, 42, 1187-1192.

Lopez-Martinez, L. X., Parkin, K. L., \& Garcia, H. S. (2011). Phase IIinducing, polyphenols content and antioxidant capacity of corn (Zea mays L.) from phenotypes ofwhite, blue, red and purple colors processed into masa and tortillas. Plant Foods for Human Nutrition, 66(1), 41-47. http://dx.doi.org/10.1007/s11130-0110210-z. PMid:21327968.
Miller, H. E., Rigelhof, F., Marquart, L., Prakash, A., \& Kanter, M. (2000). Antioxidant content of whole grain breakfast cereals, fruits and vegetables. Journal of the American College of Nutrition, 19(Suppl. 3), 312S-319S. PMid:10875603.

Mora-Rochin, S., Gutiérrez-Uribe, J. A., Serna-Saldivar, S. O., SánchezPeña, P., Reyes-Moreno, C., \& Milán-Carrillo, J. (2010). Phenolic content and antioxidant activity of tortillas produced from pigmented maize processed by conventional nixtamalization or extrusion cooking. Journal of Cereal Science, 52(3), 502-508.

Moussa-Ayoub, T. E., Youssef, K., El-Samahy, S. K., Kroh, L. W., \& Rohn, S. (2015). Flavonol profile of cactus fruits (Opuntia fi cusindica) enriched cereal-based extrudates: authenticity and impact of extrusion. Food Research International, 78, 442-447. http://dx.doi. org/10.1016/j.foodres.2015.08.019. PMid:28433313.

Nayak, B., Berrios, J. J., Powers, J. R., \& Tang, J. (2011). Effect of extrusion on the antioxidant capacity and color attributes of expanded extrudates prepared from purple potato and yellow pea flour mixes. Journal of Food Science, 76(6), C874-C883. http://dx.doi.org/10.1111/j.17503841.2011.02279.x. PMid:22417485.

Nayak, B., Liu, R. H., \& Tang, J. (2015). Effect of processing on phenolic antioxidants of fruits, vegetables, and grains-a review. Critical Reviews in Food Science and Nutrition, 55(7), 887-919. http://dx.doi. org/10.1080/10408398.2011.654142. PMid:24915381.

Okarter, N., Liu, C. S., Sorrells, M. E., \& Liu, R. H. (2010). Phytochemical content and antioxidant activity of six diverse varieties of whole wheat. Food Chemistry, 119(1), 249-257. http://dx.doi.org/10.1016/j. foodchem.2009.06.021.

Paraman, I., Sharif, M. K., Supriyadi, S., \& Rizvi, S. S. H. (2015). Agrofood industry byproducts into value added extruded foods. Food and Bioproducts Processing, 96, 78-85. http://dx.doi.org/10.1016/j. fbp.2015.07.003.

Parra, C., Saldivar, S. O., \& Liu, R. H. (2007). Effect of processing on the phytochemical profiles and antioxidant activity of corn for production of masa, tortillas, and tortilla chips. Journal of Agricultural and Food Chemistry, 55(10), 4177-4183. http://dx.doi.org/10.1021/ jf063487p. PMid:17455952.

Pękal, A., \& Pyrzynska, K. (2014). Evaluation of aluminium complexation reaction for flavonoid content assay. Food Analytical Methods, 7(9), 1776-1782. http://dx.doi.org/10.1007/s12161-014-9814-x.

Re, R., Pellegrini, N., Proteggente, A., Pannala, A., Yang, M., \& RiceEvans, C. (1999). Antioxidant activity applying an improved ABTS radical cation decolorization assay. Free radical biology and medicine, 26(9-10), 1231-1237.

Reis, S. F., Rai, D. K., \& Abu-Ghannam, N. (2014). Apple pomace as a potential ingredient for the development of new functional foods. International Journal of Food Science \& Technology, 49(7), 1743-1750. http://dx.doi.org/10.1111/ijfs.12477.

Remy, S., Fulcrand, H., Labarbe, B., Cheynier, V., \& Moutounet, M. (2000). First confirmation in red wine of products resulting from direct anthocyanin-tannin reactions. Journal of the Science of Food and Agriculture, 80(6), 745-751. http://dx.doi.org/10.1002/ (SICI)1097-0010(20000501)80:6<745::AID-JSFA611>3.0.CO;2-4. PMid:29345778.

Reyes, L. F., Villarreal, J. E., \& Cisneros-Zevallos, L. (2007). The increase in antioxidant capacity after wounding depends on the type of fruit or vegetable tissue. Food Chemistry, 101(3), 1254-1262. http://dx.doi. org/10.1016/j.foodchem.2006.03.032.

Rocha-Guzmán, N. E., Gallegos-Infante, J. A., Delgado-Nieblas, C. I., Zazueta-Morales, J. J., Gonzalez-Laredo, R. F., CervantesCardoza, V., Martínez-Bustos, F., \& Aguilar-Palazuelos, E. (2012). Effect of extrusion cooking on the antioxidant activity of extruded 
half product snacks made of yellow corn and pumpkin flours. International Journal of Food Engineering, 8(4), 1-13. http://dx.doi. org/10.1515/1556-3758.2284.

Vázquez-Carrillo, M. G., Aparicio-Eusebio, L. A., Salinas-Moreno, Y., Buendía-Gonzalez, M. O., \& Santiago-Ramos, D. (2018). Nutraceutical, physicochemical, and sensory properties of blue corn polvorones, a traditional flour-based confectionery. Plant Foods for Human Nutrition, 73(4), 321-327. http://dx.doi.org/10.1007/s11130-0180692-z. PMid:30284109.
Zeng, Z., Luo, S., Liu, C., Hu, X., Gong, E., \& Miao, J. (2018). Phenolic retention of brown rice after extrusion with mesophilic $\alpha$-amylase. Food Bioscience, 21, 8-13. http://dx.doi.org/10.1016/j.fbio.2017.10.008.

Zieliński, H., Kozlowska, H., \& Lewczuk, B. (2001). Bioactive compounds in the cereal grains before and after hydrothermal processing. Innovative Food Science \& Emerging Technologies, 2(3), 159-169.

Zieliński, H., Michalska, A., Piskula, M. K., \& Kozlowska, H. (2006). Antioxidants in thermally treated buckwheat groats. Molecular Nutrition \& Food Research, 50(9), 824-832. http://dx.doi.org/10.1002/ mnfr.200500258. PMid:16917808. 